\title{
THE EPIDEMIOLOGICAL OVERVIEW OF ACUTE FLACCID PARALYSIS CASES IN SURABAYA DURING 2014-2017
}

\author{
Gambaran Epidemiologi Kasus Acute Flaccid Paralysis di Kota Surabaya Tahun 2014-2017
}

\section{Dwiki Noni Armyta}

Public Health Faculty, Universitas Airlangga, dwiki.noni.armyta-2015@fkm.unair.ac.id Corresponding Author: Dwiki Noni Armyta, dwiki.noni.armyta-2015@fkm.unair.ac.id, Department of Epidemiology, Public Health Faculty, Universitas Airlangga, Dr. Ir. H. Soekarno Street, Mulyorejo, Surabaya City, East Java, Postal Code 60115

\section{ARTICLE INFO \\ Article History: \\ Received April, $18^{\text {th }}, 2019$ \\ Revised form May, $8^{\text {th }}, 2019$ \\ Accepted July, $17^{\text {th }}, 2019$ \\ Published online August, 30 ${ }^{\text {th }}, 2019$}

\section{Keywords:}

acute flaccid paralysis; guillain barre syndrome; surabaya;

surveillance

\section{Kata Kunci:}

acute flaccid paralysis;

guillain barre syndrome;

surabaya;

surveilans

\begin{abstract}
Background: During 2017 to 2018,168 polio cases were found globally that caused an increase of awareness towards the emergence of poliovirus in Indonesia. AFP surveillance was the primary strategy to overcome global polio. Therefore, the understanding of the epidemiological characteristics becomes very important to improve the success of AFP surveillance systems. Purpose: This study aims to describe the epidemiological characteristics and types of diagnosis of AFP cases in Surabaya from 2014 to 2017. Method: This study was a descriptive study with a case series design. Data sources utilized was secondary data from AFP surveillance report of Surabaya City Health Office from 2014 to 2017. Results: Total AFP cases in Surabaya from 2014 to 2017 recorded 54 cases with annual AFP Non-Polio Incidence rate of approximately 3.85/100,000 children aged $<15$ years old in 2017. The result of the final diagnosis was Guillain Barre Syndrome (GBS) (44.44\%). AFP mostly affected children in the age of group 1-4 years old (42.59\%). Most AFP cases occurred in men (74.07\%) and were more commonly found in areas with a high population density. The increasing case pattern occurred in October in the last two years. Conclusion: The AFP Non-Polio case finding in Surabaya was classified high with the highest case pattern during 2014-2017. The incidents occurred in male at the age group 1-4 years old, and Guillain Barre Syndrome became the most common case diagnosis.
\end{abstract}

C2019 Jurnal Berkala Epidemiologi. Published by Universitas Airlangga. This is an open access article under CC-BY-SA license (https://creativecommons.org/licenses/by-sa/4.0/)

\section{ABSTRAK}

Latar Belakang: Pada rentang tahun 2017 hingga 2018 tercatat ditemukan 168 kasus polio di dunia yang menyebabkan peningkatan kewaspadaan terhadap masuknya virus polio ke Indonesia. Surveilans AFP merupakan strategi utama upaya eradikasi polio global, sehingga pemahaman mengenai karakteristik epidemiologi penting untuk meningkatkan keberhasilan sistem surveilans AFP. Tujuan: Penelitian ini bertujuan untuk mendeskripsikan karakteristik epidemiologi dan jenis-jenis diagnosis dari kasus AFP di Surabaya selama tahun 2014 hingga 2017. Metode: penelitian ini adalah studi 
deskriptif dengan rancang bangun case series. Sumber data yang digunakan adalah data sekunder surveilans AFP di Dinas Kesehatan Kota Surabaya tahun 2014-2017. Hasil: Total kasus AFP di Kota Surabaya selama tahun 2014 hingga 2017 tercatat sebanyak 54 kasus dengan Incidence rate tahunan kasus AFP Non Polio sekitar 3,85/100.000 pada anak dengan usia < 15 tahun pada 2017. Mayoritas diagnosis akhir kasus terbanyak adalah Guillain Barre Syndrome (GBS) (44,44\%). Kasus AFP paling banyak diderita anakanak pada kelompok usia 1-4 tahun (42,59\%). Sebagian besar kasus AFP terjadi pada laki-laki (74,07\%). Kasus AFP lebih sering ditemukan di wilayah yang memiliki kepadatan penduduk tergolong tinggi. Pola peningkatan kasus terjadi pada bulan Oktober dalam dua tahun terakhir. Kesimpulan: Penemuan kasus AFP Non Polio di Kota Surabaya tergolong tinggi dengan pola kejadian pada tahun 2014-2017 paling tinggi terjadi pada laki-laki dengan kelompok usia 1-4 tahun dan Guillain Barre Syndrome sebagai diagnosis akhir kasus terbanyak.

(C2019 Jurnal Berkala Epidemiologi. Penerbit Universitas Airlangga. Jurnal ini dapat diakses secara terbuka dan memiliki lisensi CC-BY-SA (https://creativecommons.org/licenses/by-sa/4.0/)

\section{INTRODUCTION}

Presently, almost all of the countries acquired polio-free certification, including Indonesia in 2014. This certification began in 1988, the World Health Organization (WHO) adopted the Global Polio Eradication Initiative; it aimed to eliminate polio in 2000 . Therefore, the WHO recommended the countries to create a case surveillance system for Acute Flaccid Paralysis (AFP) symptoms (Odoom et al., 2014). AFP became a priority on public health and became the main focus on polio surveillance implementation (Macesic et al., 2016).

Poliovirus was not found in Indonesia since 2005. However, in 2006, there was an increase of polio cases which caused an outbreak with 46 cases located in East Java Province. The recent report from the Ministry of Health of Indonesia stated that from 2017 to 2018 , there were 168 polio cases all over the world, and 9 cases were found in Papua New Guinea. This situation triggered an emersion of warning from The Ministry of Health to improve the preventive actions towards the emergence of poliovirus in Indonesia. The emersion of this polio case became a challenge for global polio eradication. As long as a single child found infected by polio, then all children in the world still have the same risks to be infected by polio (Khona, Prayag, \& Ashtagi, 2016). These risks also became a challenge to the city with the highest population in East Java Province like Surabaya. The total population of
Surabaya was $\pm 2,862,406$ people with the population density around 8.770 people $/ \mathrm{km} 2$ and the highest total population aged $<15$ years old as much as 626,805 children (Health Office of East Java Province, 2018).

AFP Surveillance is the primary strategy to monitor global polio elimination progress. The strategy is effective in early detecting a potency of poliomyelitis or poliovirus infection cases (Soltani, Esmailnasab, Roshani, Karimi, \& Amjadi, 2014). AFP Surveillance is one of the four pillar strategies of polio eradication in finding all polio cases by targeting all AFP cases as potential polio cases (Makoni et al., 2017). AFP is defined as paralysis in any part of the body, called flaccid, occur suddenly on children aged $<15$ years old. AFP is acute because the paralysis occurred in the quick time between 1-14 days since the onset of symptoms such as tingling, soreness, numbness until the maximum paralysis. The paralysis is characterized by flaccid or limp, and it is not because of the stiffness or decrease in the tonus and overworked (Ministry of Health RI, 2007).

WHO estimates many diagnoses are classified into AFP cases, and as more than 200 diagnoses are assessed, polio is just one of the causes (Ministry of Health RI, 2007). Other diagnoses included in the AFP case are Guillain Barre Syndrome (GBS), transverse myelitis, transient paralysis, traumatic neuritis, etc (Odoom et al., 2014). AFP cases have different epidemiological characteristics as the aetiology of AFP heterogeneity (Jasem et al., 2014). The differences 
in AFP diagnosis vary by region. For example, in Australia, the diagnosis of Acute Disseminated Encephalomyelitis (ADEM) is included in the AFP case. In Nigeria, AFP classification consists of a diagnosis of traumatic sciatic nerve palsy, but GBS remains as the most common cause of non-polio AFP cases all over the world (Mohsin \& Asimi, 2016).

The efforts to detect polio cases and the diversity of AFP diagnoses are required to understand the epidemiological characteristics of diseases. These efforts are essential to increase the success of the AFP surveillance system in detecting polio cases. The purpose of this study was to describe epidemiological characteristics and types of diagnosis of AFP cases in Surabaya from 2014 to 2017 by describing the cases based on person, place, and time variables.

\section{METHOD}

This study is a descriptive study with a case series design to describe the epidemiological characteristics of AFP cases of AFP surveillance implementation in Surabaya from 2014 to 2017. Sources of data employed in this study were secondary data from AFP surveillance report taken from Surabaya Health Office during 2014-2017. The data was also supported by the data obtained from the Health Profile of East Java, Health Profile of Surabaya, WHO, and other published reports.

The analysis employed a univariate analysis to find out the overview of the frequency distribution, the type of final diagnosis, and overview based on the person (age, sex), place (geographical condition), and time variables. The final diagnosis of AFP cases is divided into five types, Guillain Barre Syndrome (GBS), Chikungunya, Paralysis, Paraparesis. Age variables are divided into four groups included < 1-year-old, 1-4 years old, 5-8 years old, and 10-15 years old.

\section{RESULTS}

\section{AFP Surveillance in Surabaya}

The total finding of AFP cases in Surabaya from 2014 to 2017 was 54 cases. Surabaya has a target to find AFP cases as many as 16 cases each year. The NPAFP rate in Surabaya decreased from 2014 to 2015 , but the rate continued to increase in the following years. There were no positive polio cases found. The NPAFP rate of Surabaya exceeded the national NPAFP target in 2017 (Table 1).

Table 1

AFP Cases and NPAFP Rate in Surabaya during 2014-2017

\begin{tabular}{ccrc}
\hline Year & $\begin{array}{c}\text { Population } \\
\text { aged }<15 \text { years } \\
\text { old }\end{array}$ & Cases & $\begin{array}{c}\text { Non Polio } \\
\text { AFP rate }\end{array}$ \\
\hline 2014 & 637,995 & 20 & 3.31 \\
2015 & 630,609 & 4 & 0.63 \\
2016 & 626,805 & 6 & 0.96 \\
2017 & 622,704 & 24 & 3.85 \\
\hline
\end{tabular}

Overview of Final Diagnosis of AFP Cases in Surabaya during 2014-2017

The final diagnosis majority (44.44\%) of AFP cases was Guillain Barre Syndrome (GBS) (Table 2). The type diagnosis diseases classified in AFP cases from 2014 to 2017 changed to become more diverse from year to year (Figure 1).

Table 2

Final Diagnosis of AFP Cases in Surabaya during 2014-2017

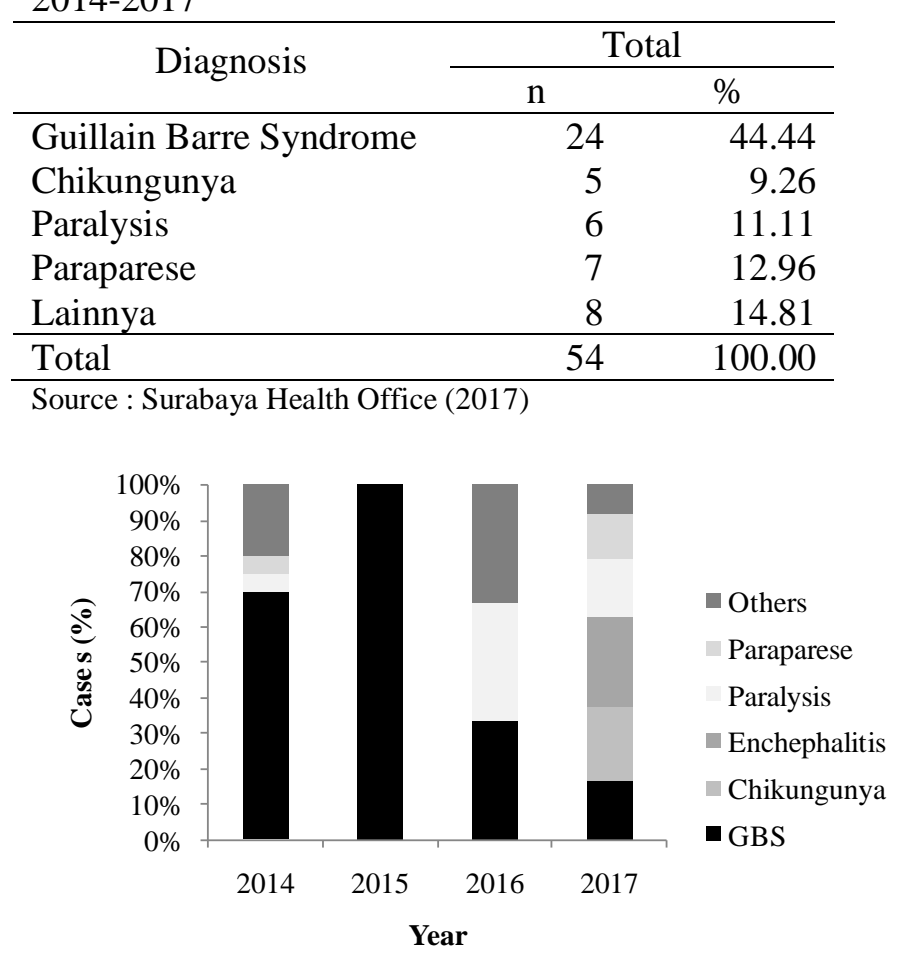

Source : Surabaya Health Office (2017)

Figure 1. Types of AFP Cases Final Diagnosis in Surabaya during 2014-2017 
Overview of AFP Cases Based on Person Variable

AFP cases finding based on age groups from 2014 to 2017 mostly affected children in the age group 1-4 years old. Based on sex, the majority of AFP cases were more common in men than women (Table 3).

\section{Overview of AFP Cases Based on Place Variable}

Based on the mapping results of AFP cases according to the place, it was suggested that AFP cases occurred throughout Surabaya. However, from analysis of the last four years, several region got AFP cases each year, such as Sawahan, Rungkut, Tambaksari, Sukomanunggal, Tegalsari, and Wonokromo Districts (Figure 2).

\section{Overview of AFP Cases Based on Time \\ Variable}

The overview of AFP cases in Surabaya from 2014 to 2017 fluctuated. The highest peak of case finding occurred in October 2016, almost 70\% of AFP cases were found in October 2016. The increasing cases pattern occurred in April and
October in the last two years, respectively. (Figure $3)$.

\section{DISCUSSION}

\section{AFP Surveillance in Surabaya}

The AFP surveillance system is said to be sensitive if it is able to detect at least 2 cases of AFP per 100,000 children aged $<15$ years old (Makoni et al., 2017). One indicator of the success of AFP surveillance is non-polio AFP (NPAFP) rate. NPAFP rate is the number of cases of acute wilting paralysis allegedly to be polio until proven as not polio by laboratory tests. The Indonesian Ministry of Health set a minimum NPAFP rate in Indonesia of $2 / 100,000$ children aged $<15$ years old (Ministry of Health RI, 2018). The results of this study indicate that the AFP cases finding in Surabaya has exceeded the finding target each year. This NPAFP rate also exceeded the national NPAFP target in 2017. This shows an improvement of AFP surveillance in capturing AFP cases and proving it is not polio.

Table 3

Distribution of AFP Cases Based on Age and Sex in Surabaya on 2014-2017

\begin{tabular}{lrrrrrr}
\hline & \multicolumn{5}{c}{ Cases (Years) } & \multicolumn{3}{c}{ Total } \\
\cline { 2 - 7 } & 2014 & 2015 & 2016 & 2017 & \multicolumn{1}{c}{ n } \\
\hline Age (Years Old) & & & & & & \\
$<1$ & 3 & 0 & 0 & 0 & 3 & 5,56 \\
$1-4$ & 8 & 1 & 2 & 12 & 23 & 42,59 \\
$5-9$ & 7 & 1 & 4 & 9 & 21 & 38,89 \\
$10-15$ & 2 & 2 & 0 & 3 & 7 & 12,96 \\
Sex & & & & & & \\
Men & 16 & 1 & 5 & 18 & 40 & 74,07 \\
Women & 4 & 3 & 1 & 6 & 14 & 25,93 \\
\hline Total & 20 & 4 & 6 & 24 & 54 & 100,00 \\
\hline
\end{tabular}

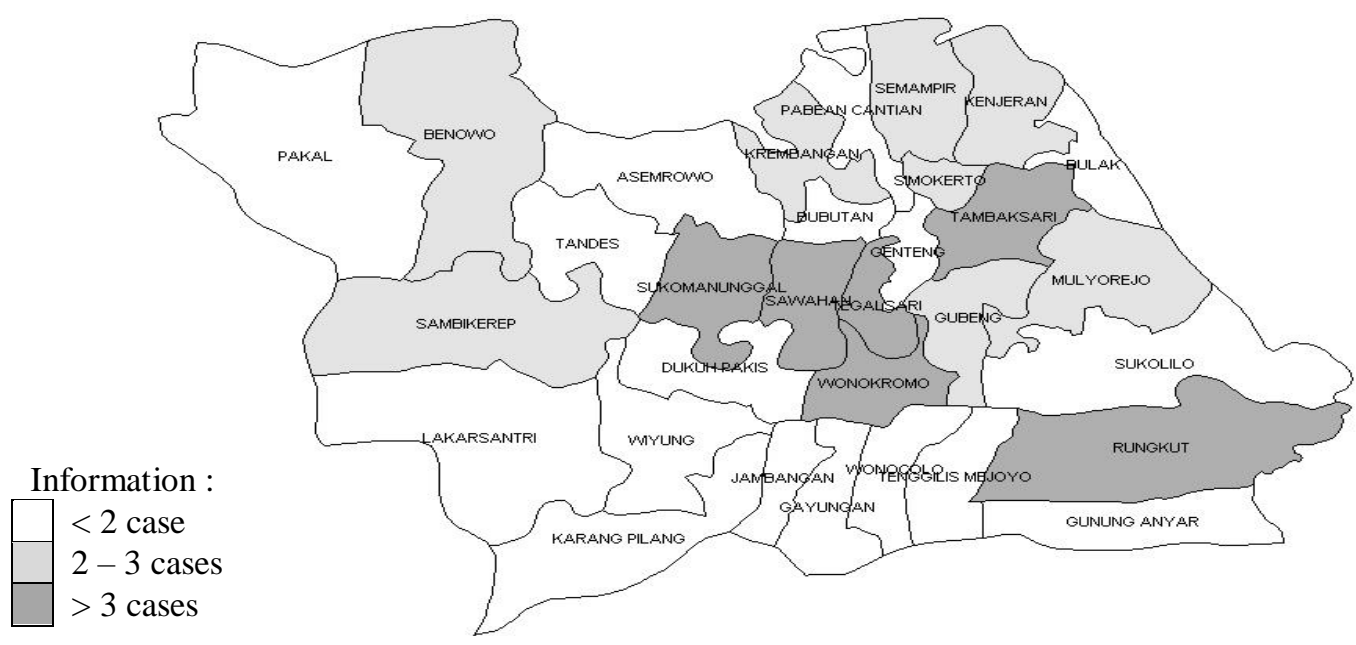

Figure 2. Distribution Map of AFP Cases Based on Districts in Surabaya in 2014-2017 


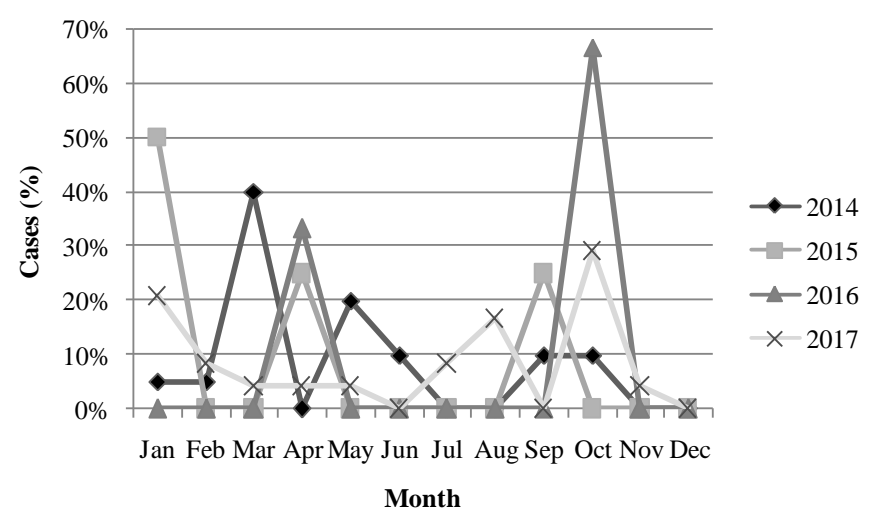

Figure 3. Overview of AFP Cases on Monthly Basis

\section{Overview of AFP Cases Final Diagnosis in Surabaya during 2014-2017}

The annual incidence rate Non-Polio AFP cases in Surabaya was approximately 3.85 per 100,000 children aged $<15$ years old per 2017 . This rate exceeded the minimum target set by WHO and national NPAFP to find out 2 cases per 100,000 children aged $<15$ years old (Ministry of Health RI, 2018).

The results of this study suggested that the final diagnosis majority of AFP cases in Surabaya was GBS (Guillain Barre Syndrome). Almost all studies related to AFP surveillance that have been conducted indicated the same results. A study in Iraq suggested that the majority of AFP cases were diagnosed as Guillain Barre Syndrome (52.50\%) (Jasem et al., 2014). The same result was also assessed in Peru, where GBS was the most common cause of acute paralytic neuropathy with annual incidents ranging from 0.50 to 2.00 per 100,000 population (Díaz-Soto, Chavez, Chaca, Alanya, \& Tirado-Hurtado, 2019). As well as the results of the study in Spain, GBS was the most common clinical diagnosis as the largest AFP cases during the 18 years of AFP surveillance from 1998 to 2015 (76.90\%) (Masa-Calles et al., 2018).

Guillain Barre Syndrome (GBS) is an asymptomatic condition of neuropathy in the peripheral nervous system that occurs suddenly due to the development of motor weakness. GBS is an acute inflammation due to demyelination of polyradiculoneuropathy from autoimmune mechanisms. Common characteristics of this syndrome are the arm and leg muscle weakness of cranial nerve stimulation system, missing or decreased tendon reflexes, and albumin cytological disassociation. Review of populations in Europe and North America showed that annual incidents of GBS ranged from $0,80-1,90$ per 100,000 people per year (Willison, Jacobs, \& van Doorn, 2016). The worldwide annual incidence of GBS ranged from 0,50-2,00 cases per 100,000 people per year (Wachira, Peixoto, \& de Oliveira, 2019).

Besides, the results of this study suggested that the diagnosis of AFP cases in 2016 and 2017 indicated pattern changes to be more diverse with encephalitis, paraparesis, chikungunya, and other diagnoses. The final diagnosis variety of AFP cases is caused by a large number of diseases included in the AFP category. According to WHO, at least more than 200 diagnoses can be classified into AFP cases (Ministry of Health RI, 2007). In another study, the second and third largest AFP diagnoses are transverse myelitis and encephalitis. The changes in the types of diagnosis are more diverse; it occurs due to the improvement of medical personnel' ability to classify the AFP symptoms in diagnosis cases (Soltani, Esmailnasab, Roshani, Karimi, \& Amjadi, 2014).

\section{Overview of AFP Cases Based on Person Variable}

The results of this study suggested that the majority of AFP cases affected children in the age group of 1-4 years old. The result was related to several studies that had been conducted before. Studies in Iran suggested that $53.30 \%$ of AFP cases occurred in boys with an average age range from $5.39 \pm 3.98$ years old (Momen \& Shakurnia, 2017). The incidence of disease with AFP clinical manifestations occurred highest in children less than six years old $(66 \%)$ with $\mathrm{RR}=5.93$ (95\% CI=3.20-10.70 ; p $<$ 0.01) (Soltani, Esmailnasab, Roshani, Karimi, \& Amjadi, 2014). Another study that was conducted in Iraq also stated that GBS was the leading cause of AFP cases. The result was indicated by the majority of AFP cases in children with the age group of 1-4 years old were infected by GBS. The tendency of AFP cases occurred in children was because the age range tends to be more susceptible to infection and peripheral nerve demyelination (Jasem et al., 2014).

The research results indicated that the ratio of boys being exposed to AFP was higher than that of girls. The same result was also found in a study in India that showed around $65.90 \%$ of AFP cases occurred in men (Khona, Prayag, \& Ashtagi, 2016). One of the causes that the boys were more vulnerable to be affected by AFP because they were more easily infected by GBS (Guillain Barre Syndrome). One of the dominant risk factors for 
GBS is sex; a study suggested that the incidence of GBS is 1.50 times more common in men than women (Ansari, Basiri, Derakhshan, Kadkhodaei, \& Okhovat, 2018). A study by Momen \& Shakurnia (2017) also suggested similar results that GBS cases in children under 15 years old are more common in boys than girls. Other studies that had been conducted indicated similar findings that around $63.50 \%$ of GBS cases occurred in men, although the t-test results suggested that there were no significant differences between men and women were found with a p-value of 0.95 (Ghazavi, Moghim, Sabaghi, Fadaei, \& Naeini, 2015). The results of other similar study also showed that higher percentage of GBS cases occurred in men (55\%) than women, although the calculation did not statistically show the significant difference $(\mathrm{RR}=0.93$; 95\% CI: 0,771.12; $\mathrm{p}=0.05$ ) (Soltani, Esmailnasab, Roshani, Karimi, \& Amjadi, 2014). The exact cause of why more cases occurred in men is yet to be explained by any studies or literature. The reasons for the tendencies in age and sex still have not been answered, especially in autoimmune diseases (Hughes, Cornblath, \& Willison, 2016). The research results on this person as variable indicated the tendency of AFP cases to be found more in boys and in the age group 1-4 years old. This result can be taken into consideration in determining vulnerable groups to prevent poliovirus infections.

\section{Overview of AFP Cases Based on Place Variable}

The results of the analysis in the last four years suggested that several regions were vulnerable to AFP cases annually, such as Sawahan, Rungkut, Tambaksari, Sukomanunggal, Tegalsari, and Wonokromo Districts. All of the six districts have similarity in terms of population density (Surabaya Health Office, 2017). The result was related to a study of AFP regarding the analysis factors in Indonesia. This analysis was affecting the AFP cases by employing generalized poison regression test. This study stated that one of the elements that significantly influence the number of AFP cases was population density. In the study, it was noted that every $1 \%$ increase in population density would affect $1 \%$ addition of the AFP cases (Deliana, Yendra, \& Desvina, 2018). Population density is associated with NPAFP rate, where the immunological susceptibility and sanitary hygiene conditions enabled the spread of infectious agents in a densely populated neighborhood (Maan, Dhole, \& Chowdhary, 2019).

Study-related to GBS conducted in Khuzestan, Iran analyzed trends in the GBS incidence geographically by dividing the region into two categories (urban and rural). The average incidence rating was 1.62 in the urban area, and 1.28 in the rural area per 100,000 people annually. Statistically, the value of the incidence rate between villages and cities shows insignificant results with a p-value of 0.09 (Momen \& Shakurnia, 2017). Information on the mapping results of the AFP case can be considered in supporting polio eradication. By increasing immunization coverage, it will make the immunization to be more effective and targeted.

\section{Overview of AFP Cases Based on Time Variable}

Study-related to AFP cases based on season characteristics in countries which have two seasons like Indonesia is still limited. Most of the studies on the epidemiology of AFP and GBS are carried out in four-season countries. Study on the incidence of GBS based on a seasonal analysis was conducted in at the John Radcliffe Hospital, Oxford during 2001-2012. The result suggested that there was $14 \%$ increase in the risk of developing GBS in winter compared to summer $(\mathrm{IRR}=1.14 ; \quad 95 \% \mathrm{CI}=1.02-1.27 ; \mathrm{p}=0.02)$ $(\mathrm{IRR}=1.14 ; 1.02-1.27 ; \mathrm{p}=0.02)$ (Webb, Brain, Wood, Rinaldi, \& Turner, 2017).

The results in this study suggested that the AFP cases highest peak in Surabaya occurred in October 2016. The increasing pattern of AFP cases occurred in April and in October for the past two years. A study of the AFP that had been done in India stated that the cases occurred throughout the year with the most significant percentage in the monsoon month period (June to September) (Maan et al., 2019). Monsoon is a weather phenomenon caused by thermal effects which can affect rainfall in a region. This phenomenon includes winter monsoon (November-March) and summer monsoon (end May-September). The monsoon region is located at $250 \mathrm{SL}-350 \mathrm{NL}$ and $300 \mathrm{LW}$ 1700LE. Thus, Indonesia is categorized in the monsoon-affected area. The area lies along with other Southeast Asian countries such as eastern India, southern China, Myanmar, Thailand, Vietnam, Laos, Cambodia, Malaysia, Singapore, Borneo, Philippines, and West Papua New Guinea. Different monsoon climates characterize the most densely populated region in the Asian continent. 
The area is ranged from the extratropic in East Asia to the Indian subcontinent $(\mathrm{Li}$, Ting, \& Lee, 2018).

In October until April, Indonesia experiences rainy season. One of the reasons this happens is because of the winter monsoon phenomenon (winter monsoon). In the winter monsoon period, the sun position is located on the southern hemisphere (Australia region), causing higher temperature with low pressure in Australia. At the same time, the temperature in the Asian region becomes lower with high pressure. The differences in temperature and pressure affected the wind direction, thus causing the rainy season in Indonesia (Loo, Billa, \& Singh, 2015). In October to March, the average temperature in Indonesia, especially in East Java province ranged from 20.50 to $22.40^{\circ} \mathrm{C}$. The average rainfall in Surabaya every month is $248 \mathrm{~mm}$, while rainfall of more than 500 $\mathrm{mm}$ at Juanda Station occured in February and October (Indonesian Central Bureau of Statistics, 2015).

The monsoon phenomenon is very influential on the determination of seasons in Indonesia, both rainy and dry seasons (Loo et al., 2015). Another study said summer monsoon causes $80 \%$ of annual rainfall, which affects the local economy, agriculture, ecosystems, and health ( $\mathrm{Li}$ et al., 2018).

Weather factors create a variety of environmental and social conditions, which led to the emerging of many infectious diseases in humans and animals. Climate and weather conditions also play a role in causing outbreaks of contagious diseases in several regions (McMichael, 2015). Weather and climate components such as air temperature, humidity level, and rainfall as well as wind speed and direction can affect the survival of viruses and pathogens. These components indirectly affect the condition of the human immune system. This condition is caused by climate changes that can increase the biting rate and vector reproduction rate and also shorten the pathogen incubation period (Chowdhury et al., 2018). This season's depiction of AFP cases can be used as information for monitoring and early detection so that it can increase the vigilance of medical personnel to carry out prevention in the case-increasing month.

\section{Study Limitations}

The overview of AFP cases in Surabaya suggested that the highest number of final diagnosis of AFP cases was GBS (Guillain Barre Syndrome). The AFP cases affected most children in the age group of 1-4 years old and more common in boys. AFP cases were often found in regions that have a high population density. The increasing cases pattern occurred in October for two years, respectively.

\section{ACKNOWLEDGEMENT}

The author would like to express her gratitude profusely to the Health Office of Surabaya, which provides the data utilized in this study and other parties that have helped through the process of writing this article.

\section{REFERENCES}

Ansari, B., Basiri, K., Derakhshan, Y., Kadkhodaei, F., \& Okhovat, A. (2018). Epidemiology and clinical features of guillain-barre syndrome in Isfahan, Iran. Advanced Biomedical Research, 7, 87. https://doi.org/10.4103/abr.abr_50_17

Chowdhury, F. R., Ibrahim, Q. S. U., Shafiqul Bari, M., Jahangir Alam, M. M., Dunachie, S. J., Rodriguez-Morales, A. J., \& Ismail Patwary, M. (2018). The association between temperature, rainfall and humidity with common climate-sensitive infectious diseases in Bangladesh. PLoS ONE, 13(6), 1-17. https://doi.org/10.1371/journal.pone.0199579

Deliana, S., Yendra, R., \& Desvina, A. P. (2018). Factor analysis that affecting cases of acute flaccid paralysis (AFP) in Indonesia using generalized poisson regression. STNKI, 10(1), 605-612.

Díaz-Soto, S., Chavez, K., Chaca, A., Alanya, J., \& Tirado-Hurtado, I. (2019). Outbreak of guillain-barre syndrome in Peru. ENeurologicalSci, $\quad 14(2), \quad 89-90$. https://doi.org/10.1016/j.ensci.2019.02.001

Ghazavi, M., Moghim, S., Sabaghi, A., Fadaei, R., \& Naeini, A. (2015). Acute flaccid paralysis surveillance: A 6 years study, Isfahan, Iran. Advanced Biomedical Research, 4(1), 99. https://doi.org/10.4103/2277-9175.156670

Health Office of East Java Province. (2018). Health profile of East Java Province in 2017. Health Office of East Java Province. Surabaya City.

Hughes, R. A. C., Cornblath, D. R., \& Willison, H. J. (2016). Guillain-barré syndrome in the 100 years since its description by Guillain, Barré and Strohl. Brain: A Journal of Neurology, 139(11), 3041-3047. https://doi.org/10.1093/brain/aww247

Indonesian Central Bureau of Statistics. (2015). 
Report the average temperature of $B M K G$ observations. Central Bureau of Imdonesia Statistics. Jakarta. Retrieved April 18, 2019, from

https://www.bps.go.id/statictable/2017/02/09/ 1961/suhu-minimum-rata-rata-danmaksimum-di-stasiun-pengamatan-bmkg-oc2011-2015.html

Jasem, J. A., Marof, K., Nawar, A., Khalaf, Y., AlHamdani, F., Ali, S., ... Islam, K. M. M. (2014). An epidemiological analysis of acute flaccid paralysis and its surveillance system in Iraq, 1997-2011. BMC Infectious Diseases, 14(48), 1-9. https://doi.org/10.1186/14712334-14-448

Khona, P., Prayag, A., \& Ashtagi, G. (2016). Study of acute flaccid paralysis cases at tertiary care hospital Belagavi, Karnataka. International Journal of Medical Science and Public Health, 6(2), 398-401. https://doi.org/10.5455/ijmsph.2017.1808201 6630

Li, X., Ting, M., \& Lee, D. E. (2018). Fast adjustments of the Asian summer monsoon to anthropogenic aerosols. Geophysical Research Letters, 45(2), 1001-1010. https://doi.org/10.1002/2017GL076667

Loo, Y. Y., Billa, L., \& Singh, A. (2015). Effect of climate change on seasonal monsoon in Asia and its impact on the variability of monsoon rainfall in Southeast Asia. Geoscience Frontiers, 6(6), 817-823. https://doi.org/10.1016/j.gsf.2014.02.009

Maan, H. S., Dhole, T. N., \& Chowdhary, R. (2019). Identification and characterization of nonpolio enterovirus associated with nonpolio-acute flaccid paralysis in polio endemic state of Uttar Pradesh, Northern India. PLoS ONE, 14(1), 1-18. https://doi.org/10.1371/journal.pone.0208902

Macesic, N., Hall, V., Mahony, A., Hueston, L., Ng, G., Macdonell, R., ... Grayson, M. L. (2016). Acute flaccid paralysis: the new, the old, and the preventable. Open Forum Infectious Diseases, 3(1), 1-4. https://doi.org/10.1093/ofid/ofv190

Makoni, A., Chemhuru, M., Gombe, N., Shambira, G., Juru, T., Bangure, D., \& Tshimanga, M. (2017). Evaluation of the acute flaccid paralysis (AFP) surveillance system, Gokwe North district, Zimbabwe, 2015: a descriptive cross sectional study. Pan African Medical Journal, 27(203), 1-5. https://doi.org/10.11604/pamj.2017.27.203.1 0956
Masa-Calles, J., Torner, N., López-Perea, N., Torres de Mier, M. de V., FernándezMartínez, B., Cabrerizo, M., ... Castrillejo, D. (2018). Acute flaccid paralysis (AFP) surveillance: challenges and opportunities from 18 years' experience, Spain, 1998 to 2015. Eurosurveillance, 23(47), 1-13. https://doi.org/10.2807/15607917.es.2018.23.47.1700423

McMichael, A. J. (2015). Extreme weather events and infectious disease outbreaks. Virulence, 6(6), 543-547. https://doi.org/10.4161/21505594.2014.9750 22

Ministry of Health RI. (2007). Decree of the Minister of Health of the Republic of Indonesia no. 483 of 2007 concerning guidelines for surveillance of acute flaccid paralysis (AFP). Jakarta: Ministry of Health RI.

Ministry of Health RI. (2018). Indonesian health profile in 2017. Ministry of Health RI. Jakarta.

Mohsin, N., \& Asimi, R. (2016). Clinical profile of acute flaccid paralysis. The Medical Journal of Malaysia, 4(2), 196-200. https://doi.org/10.4103/2321-4848.196193

Momen, A. A., \& Shakurnia, A. (2017). The epidemiology of guillain-barré syndrome in children under 15 years old in Southwest Iran. Biomedicine Hub, 2(3), 1-8. https://doi.org/10.1159/000480693

Odoom, J. K., Afia, N., Ntim, A., Sarkodie, B., Addo, J., Minta-asare, K., ... Barnor, J. S. (2014). Evaluation of AFP surveillance indicators in polio-free Ghana, 2009-2013. BMC Public Health, 14(687), 1-8. Retrieved from http://www.biomedcentral.com/14712458/14/687

Soltani, J., Esmailnasab, N., Roshani, D., Karimi, M., \& Amjadi, M.-J. (2014). Acute flaccid paralysis and its differential diagnosis in in kurdistan province, Western iran; an 11-year surveillance. Iranian Journal of Pediatrics, 24(2), 131-139.

Surabaya Health Office. (2017). Health profile of Surabaya City in 2016. Surabaya Health Office. Surabaya City.

Wachira, V. K., Peixoto, H. M., \& de Oliveira, M. R. F. (2019). Systematic review of factors associated with the development of GuillainBarré syndrome 2007-2017: what has changed? Tropical Medicine and International Health, 24(2), 132-142. https://doi.org/10.1111/tmi.13181 
Webb, A. J. S., Brain, S. A. E., Wood, R., Rinaldi, S., \& Turner, M. R. (2017). Seasonal variation in Guillain-Barré syndrome: a systematic review, meta-analysis and Oxfordshire cohort study. Journal of Neurology, Neurosurgery and Psychiatry, 86(11), 1196-1201. https://doi.org/10.1136/jnnp-2014-309056

Willison, H. J., Jacobs, B. C., \& van Doorn, P. A. (2016). Guillain-barré syndrome. The Lancet, 388(10045),

717-727. https://doi.org/10.1212/CON.0000000000000 513 